The unique giant Irish moss (Chondrus crispus) from Basin Head: Health assessment in relation to reference sites on Prince Edward Island

\begin{tabular}{|r|l|}
\hline Journal: & Botany \\
\hline Manuscript ID & cjb-2018-0081.R1 \\
\hline Manuscript Type: & Note \\
\hline Author: & $12-J u n-2018$ \\
\hline $\begin{array}{r}\text { Complete List of Authors: } \\
\text { Kabmitted by the }\end{array}$ & $\begin{array}{l}\text { Tummon Flynn, Paula; University of Prince Edward Island, } \\
\text { Garbary, David; Saint Francis Xavier University Department of } \\
\text { Biology } \\
\text { Novaczek, Irene; Department of Fisheries and Oceans } \\
\text { Miller, Anthony; Department of Biology } \\
\text { Quijon, Pedro; University of Prince Edward Island, Biology }\end{array}$ \\
\hline \hline $\begin{array}{r}\text { Is the invited manuscript } \\
\text { for consideration in a } \\
\text { Special Issue? : }\end{array}$ & $\begin{array}{l}\text { Giant Irish moss, Chondrus crispus, Basin Head MPA, Atlantic } \\
\text { Canada }\end{array}$ \\
\hline \multicolumn{2}{|c|}{} \\
\hline
\end{tabular}




\title{
NOTE:
}

\section{The unique giant Irish moss (Chondrus crispus) from Basin Head: Health assessment in relation to reference sites on Prince Edward Island}

Paula Tummon Flynn ${ }^{1}$, David Garbary ${ }^{2}$, Irene Novaczek ${ }^{3}$, Anthony Miller ${ }^{2}$, Pedro A. Quijón ${ }^{1}$

${ }^{1}$ Department of Biology, University of Prince Edward Island, Charlottetown, PE, Canada

${ }^{2}$ Department of Biology, St. Francis Xavier University, Antigonish, NS, Canada

${ }^{3}$ Department of Fisheries and Oceans, Charlottetown, PE, Canada

\begin{abstract}
Irish moss (Chondrus crispus Stackhouse) is a common red alga of the Atlantic Canada region. A unique strain of this species, the giant Irish moss, grows in a single location and is under strict protection. Unlike the common coastal form, the giant Irish moss reproduces solely by fragmentation and is found in gametophyte form. A $99.9 \%$ decline in giant Irish moss abundance (1999-2012) prompted this study to address two questions: whether the giant Irish moss remains $100 \%$ vegetative and gametophytic, and whether such decline is related to factors leading to a reduction in photosynthetic health. Six populations of the common Irish moss strain were compared with two populations of giant Irish moss, and their life history phases determined using a resorcinol method. The common Irish moss populations exhibited a $65-86 \%$ ratio of gametophytic:tetrasporophytic fronds, while both giant strain populations were $100 \%$ gametophytic. Photosynthetic efficiency was measured with PAM fluorometry and neither giant moss had significantly different quantum yield values from the littoral
\end{abstract}


populations. Hence, these analyses provided no evidence of giant Irish moss being exposed to particular sources of stress linked to water or habitat quality and alternative factors explaining the decline of this unique strain are proposed.

KEYWORDS: Giant Irish moss, Chondrus crispus, Basin Head MPA, Atlantic Canada

\section{INTRODUCTION}

Irish moss (Chondrus crispus Stackhouse) is an abundant red alga widely distributed in the North Atlantic Ocean, including the Canadian Maritimes (Bird and McLachlan 1992) and Prince Edward Island (hereafter PEI; McLachlan et al. 1987). Irish moss plants that originate from spores are attached to hard substrates by discoid holdfasts (Taylor et al. 1981), and may be gametophytic (male and female) or asexual (tetrasporophytic) (Taylor 1962; Mathieson and Prince 1973; Mathieson and Burns 1975; Sharp 1987; McLachlan et al. 1989; McLachlan 1991). In 1976, a distinct strain of Irish moss was identified in Basin Head, a coastal lagoon near the eastern point of PEI (Judson et al. 1987). This strain differs from the most common form in its ploidy structure (i.e. 100\% gametophyte), frond morphology and method of attachment (Sharp et al. 2003), and is often referred to as giant Irish moss because of its broad fronds. This strain is free-floating due to the lack of a holdfast and grows in association with blue mussels (Mytilus edulis) that anchor clumps of Irish moss to the bottom using their byssal threads. The giant Irish moss has only been found in gametophyte form, reproducing vegetatively by fragmentation with no published records of active sexual reproductive structures (Judson et al. 1987; Sharp et al. 2010a,b).

The giant Irish moss was historically restricted to a $1 \mathrm{~km}$ stretch of the Northeast Arm of Basin Head lagoon (McCurdy 1980). In 2005, Basin Head was declared a Marine 
Protected Area (MPA) under the Ocean's Act with the purpose of protecting this unique strain. Unfortunately, between 1999 and 2012, the abundance of giant Irish moss declined by $99.9 \%$, raising questions about the causes of such decline and concern among those interested in the conservation of the Basin Head ecosystem (Sharp et al. 2010a). Accordingly, this study was undertaken to assess the health and life history phase variation of the remaining clumps of giant Irish moss at Basin Head. The first objective of this study was to determine if despite the drastic loss of biomass, the giant Irish moss in Basin Head remains purely vegetative and gametophytic (Sharp et al. 2010a,b). The second objective was to assess the photosynthetic health of the remaining giant Irish moss clumps by comparing this strain with populations of common Irish moss growing in similar habitats across PEI. The working hypothesis was that the decline of the giant Irish moss in Basin Head is related to environmental factors that lead to a reduction in photosynthetic health.

\section{METHODS}

\section{Sample collection}

Eight intertidal populations of Irish moss were sampled across PEI estuaries on July 27-28, 2015 (Fig.1, Table 1). Six of these populations were the common coastal strain (Lazo et al. 1989) and were collected manually during low tide conditions from thalli attached by holdfasts to shells or small rocks. These populations also included the common coastal strain growing in the lagoon mouth of Basin Head. At each site, approximately 100 individual fronds were sampled haphazardly, each from a different holdfast and with a minimum distance of $10 \mathrm{~cm}$ between each plant (Scrosati and Mudge 2004; Guidone and Grace 2010; Garbary et al. 2011). All fronds sampled were deep red in colour with the exception of a few individuals from one population (Point Prim) that were green. That colour has been linked to 
a drastic reduction in phycobilisome content in shallow water thalli that are subjected to high light stress (A. Miller, Pers. Obs.) so those few exceptions were excluded from further analysis to avoid unnecessary variation from sources other than water quality. The other two populations were sampled in the east Arm of Basin Head Marine Protected Area (Fig. 1). These were from the last remaining plants of an apparently asexual population with a giant moss frond morphology (Sharp et al. 2010a,b): one of the populations had grown in situ whereas the other had been cultured in the NRC facilities in Sandy Cove, Nova Scotia since 2008, from fronds originally collected in Basin Head (hereafter referred to as Basin Head giant Irish Moss and NRC giant Irish Moss, respectively). In May 2015, fronds of these two populations were collected as part of a conservation effort to restore the giant Irish moss. Basin Head giant Irish moss plants that were attached to the disappearing mussel clumps and would otherwise have been swept out of the lagoon were placed in mussel socking, and hung on cultivation lines in Basin Head. NRC giant Irish moss was transported to Basin Head where it was also hung on cultivation lines.

\section{Life history phases}

The resorcinol method, as described by Dyck et al. (1985) and Garbary and De Wreede (1988), was used to determine life history phases. This chemical test distinguishes between gametophytes and tetrasporophytes by the presence of different carrageenans in the cell walls: primarily kappa-carrageenan in gametophytes and lambda-carrageenan in tetrasporophytes. A piece of dried thallus $(\sim 10 \mathrm{mg})$ was heated $85-90^{\circ} \mathrm{C}$ for $2 \mathrm{~min}$ in the presence of 1.0-1.5 mL of resorcinol-acetal reagent prepared according to Craigie and Leigh (1978) and Garbary and De Wreede (1988). Additional frond pieces of known life history phase were processed in parallel as controls. Results were expressed as percent gametophytic fronds (Garbary et al. 2011) for all eight populations except North Rustico. That sample did 
not survive the shipment from PEI to the testing location, St. Francis Xavier University, Antigonish, NS, in a condition appropriate for accurate testing.

\section{Irish moss health}

Irish moss health was assessed by measuring the photosynthetic efficiency of individual fronds. Fluorescence measurements based on fluorescence of Chlorophyll $a(\mathrm{Chl} a)$ in Photosystem II (PSII) were performed using a Diving-PAM (Walz GmbH, Effeltrich, Germany). Minimum fluorescence $\left(F_{o}\right)$ was induced by low irradiation pulses in dark-adapted samples to remove non-photochemical fluorescence quenching caused by the previous period of illumination by the sun. Measurement areas of each thalli were enclosed in "dark leaf clips" (Heinz Walz $\mathrm{GmbH}$ ) to maintain the end of the fiber optic probe at a constant distance from the thallus and to dark-adapt for 10 min prior to taking the readings (Garbary et al. 2014). Maximal fluorescence $\left(F_{m}\right)$ was detected following a brief (1 s) saturating flash that fully reduces PSII and temporarily allows the maximum fluorescence of the PS II chlorophyll $a$ to be measured. Variable fluorescence $\left(F_{v}\right)$ was estimated as the difference between $F_{o}$ and $F_{m}$ (Garbary and Kim 2005). The two primary endpoints in this analysis refer to a relative measure of Chl $a$ in PSII $\left(F_{o}\right)$, and the ability of the PSII reaction centres to process absorbed light (i.e. quantum yield $=F_{v} / F_{m}$ ).

\section{Data analysis}

A Chi-Square test was conducted to determine whether there were differences in relative abundances of life stages (gametophyte: tetrasporophyte) between populations. The same analysis was used to assess whether gametophyte : tetrasporophyte ratios were significantly different from the 2:1 ratio predicted at equilibrium by Garbary et al. (2011). Values for minimum fluorescence $\left(F_{o}\right)$ and maximum quantum yield $\left(F_{v} / F_{m}\right)$ data were compared among populations using One-way ANOVAs. When a significant difference was detected $(p<0.05)$, 
the means were analyzed using a posteriori Tukey's tests to identify individual differences. Variance heterogeneity and normality were checked using Levene's test and the AndersonDarling test, respectively. As these assumptions were not met for the maximum quantum yield, these data were transformed into ranks to perform a non-parametric ANOVA. All analyses were performed using Minitab (version 17.0) statistical software.

\section{RESULTS}

\section{Life history phases}

All populations were gametophyte dominant, with the six coastal strains exhibiting a ratio of gametophytic to tetrasporophytic fronds between $65 \%$ and $86 \%$. The two populations of giant moss from Basin Head and the NRC (GM-BH and GM-NRC) had 100\% gametophytic fronds (Table 1). The proportion of life history stages was significantly different between sites $(\mathrm{df}=$ $\left.6, \chi^{2}=54.73, p<0.001\right)$.

\section{Irish moss health}

The photosynthetic parameters $F_{o}$ (minimum fluorescence) and $F_{v} / F_{m}$ (quantum yield) estimated for all eight sites are summarized in Figs. 2 and 3. The average minimum fluorescence ranged between 136 and 209, with an overall mean $( \pm$ SD) of $172 \pm 25.7$. Meanwhile, the average quantum yield ranged between 0.554 and 0.690 , with an overall mean of $0.636 \pm 0.039$. Both the minimum fluorescence $\left(F_{o}\right)$ (One-Way ANOVA: $F_{7,194}=$ $14.61, p<0.001)$ and the quantum yield $\left(F_{v} / F_{m}\right)$ (One-Way ANOVA: $\left.\mathrm{F}_{7,194}=3.89, p=0.001\right)$ differed significantly among populations. The two giant moss populations as well as the population in Point Prim had significantly lower $F_{o}$ values than most of the other populations. 
However, neither giant moss population (Basin Head nor NRC) had significantly different quantum yield values $\left(F_{v} / F_{m}\right)$ from the other six populations.

\section{DISCUSSION}

\section{Life history phases}

The regional variation in gametophyte- and sporophyte-dominated algal populations is complex (e.g. De Wreede and Klinger 1988). All the Irish moss populations sampled in this study were gametophyte-dominant. This result is consistent with what has been found in other Irish moss populations in the littoral zone of Nova Scotia and New Hampshire, in which there is a clear dominance of gametophytic over tetrasporophytic fronds (Mathieson and Burns 1975; Bhattacharya 1985; Scrosati et al. 1994; Scrosati and Mudge 2004; Garbary et al. 2011). Indeed, the most comprehensive sampling of populations in Nova Scotia had gametophytes with an overall average of $77+/-5 \%$ (95\% confidence limits), higher than the 2:1 ratio predicted from a life history in which the gametophytes are divided equally (theoretically) between male and female plants (van der Meer 1990; Garbary et al. 2011). Several other collections of Irish moss from coastal PEI and the Gulf of St. Lawrence had gametophyte : tetrasporophyte ratios close to 1:1 (Craigie and Pringle 1978; Lazo et al. 1989). These grew on relatively unstable substrates, e.g. friable sandstone bedrock. Space may open up more often on such unstable substrates, allowing the bottom to be colonized by carpospores that develop into tetrasporophyte thalli, thereby diluting the dominant gametophytic phase (Garbary et al. 2011). This phenomenon was demonstrated by Bhattacharya (1984) who artificially denuded areas of a population with a high gametophyte ratio. The cleared space was recolonized with a much lower ratio of gametophytes. 
Three of the Irish moss populations sampled here were near or slightly above the 2:1 gametophyte : tetrasporophyte ratio predicted as equilibrium by Garbary et al. (2011): Meadowbank (65\%), Victoria Park (74\%), and Point Prim (72\%). Neither these populations not the Basin Head common population ( $79 \%$; on rocks) were statistically different from the 2:1 ratio (Chi square, $\mathrm{p}>0.05)$, and only Hillsborough Bridge $(86 \%)$ and the giant moss populations differed from 2:1 (Chi square, $p<0.001$ ). The Basin Head (non-giant) and Hillsborough Bridge plants had the highest gametophyte ratios of the non-giant populations and were growing on imported, hard metamorphic rock used to protect the wharf at the entrance of the lagoon and the approach of the bridge, respectively. We suggest that these stable rocks, like the hard bedrocks of Nova Scotia, may be conducive to population maintenance mainly by vegetative growth from the holdfasts rather than by germination of spores (McLachlan 1991; Scrosati et al. 1994).

While the proportion of gametophytic fronds ranged between 65 and $86 \%$ in the six PEI coastal populations of Irish moss, it was $100 \%$ in both samples of giant moss. The giant moss has remained stable at the original ratio that was reported back in 1976 (Judson et al. 1987). More important, they also remain unique. To date, only two other populations, both in Nova Scotia, had gametophytes at levels approaching 100\% (i.e. 90\% and 97\%) (Garbary et al. 2011). In addition, no reproductive structures (carposporophytes) have been observed during extensive surveys conducted throughout 2015-17 for monitoring and restoration purposes (I. Novaczek, Pers. Obs.). The exploration of genetic differences between this and other Irish moss populations is a logical next step to try to understand the uniqueness of this strain. Previous DNA analyses found no differences between giant Irish moss and coastal forms using nucleotide sequences of the internal transcribed spacers (ITS1 and ITS2) and the intervening 5.8S rRNA gene (Chopin et al. 1996). However, the use of microsatellite 
genomes to compare among Irish moss strains may provide further insight on the differences among populations (see studies by Krueger-Hadfield et al. 2011; 2013; 2015).

\section{Irish moss health}

Several possible causes have been put forward to explain the sudden decline of the giant Irish moss population in Basin Head. One of these is the high input of nutrients related to agricultural land use in the surrounding watershed that is known to affect the water quality of the lagoon. This is a concern that affects most PEI estuaries including Basin Head (Cairns 2002). Nutrient loading into Basin Head Lagoon has been causally linked to eutrophic conditions, blooms of Ulva lactuca (sea lettuce), and anoxic events (Sharp et al. 2010b). Both the mats of floating Ulva and associated increases in suspended particulate matter are expected to reduce the amount of light reaching the fronds. Our estimates of minimum fluorescence $\left(F_{o}\right)$ provide a measure of the relative chlorophyll $a$ concentrations in the thalli (Kim et al. 2006). Although the giant Irish moss fronds collected in Basin Head had some of the lowest $F_{o}$ values, they were not significantly lower than other locations, and were higher than some (e.g. Point Prim population).

The decline of the giant Irish moss may also be linked to sub-optimal conditions created by the cumulative effects of temperature spikes. The waters in which the remnant giant Irish moss population is found are shallow (10-100 cm deep; Novaczek Pers. Obs.) and therefore susceptible to fluctuations that in summer approach the upper temperature tolerance of Irish moss (Lüning et al. 1978). However, we remain cautious about this as a direct and sole cause for giant moss decline. The measurements of maximum quantum yields $\left(F_{\mathrm{v}} / F_{m}\right)$ conducted here reflect the efficiency of PSII photochemistry (Anderson et al. 1997). When those values decline, this usually reflects the development of mechanisms for photoprotection in the alga (Kim et al. 2006). $F_{\mathrm{v}} / F_{m}$ values measured in giant Irish moss were not 
significantly different from those in other coastal populations. Therefore, the results of this study do not provide causal evidence of temperature-related debilitating stress on giant Irish moss, at least not without an interaction with water quality or consumer effects as those described below.

Indirect cumulative effects of temperature or nutrients cannot be disregarded (Sharp et al. 2010b) and other factors may also account for the rapid decline of the giant Irish moss. First among them are predation, grazing and/or disturbance by epibenthic species (e.g. LutzCollins et al. 2016), particularly those that may disrupt the delicate association between the giant Irish moss and mussel byssal threads. Herbivory by Gammaridean amphipods and predation by rock crabs (Cancer irroratus) merit study, as do so the potential impacts of the non-indigenous green crab (Carcinus maenas), a species that became established in Basin Head around the time when the giant Irish moss began to decline and which preys upon mussels (Pickering and Quijón 2011; Poirier et al. 2017). The study of these species interactions, in the context of the cumulative effects of changing habitat quality, climate and land use in the surrounding watershed have driven recent research efforts aimed at the restoration of this unique strain of Irish moss (I. Novaczek Pers. Obs.).

\section{ACKNOWLEDGMENTS}

We are grateful of David Cairns and Siobhan Curry (Department of Fisheries and Oceans, Canada) for their continued support. We also thank two anonymous reviewers and the Handling Editor for their comments on an earlier version of this manuscript. Funding was provided by the DFO's Academic Research Contribution Program (ARPC). PTF and PQ also thank the Natural Sciences and Engineering Research Council Canada for their support through CGS-D scholarships and Discovery Grants, respectively. 


\section{REFERENCES}

Anderson, J.M., Park, Y.-I., and Chow, W.S. 1997. Photoinactivation and photoprotection of photosystem II in nature. Physiol. Plant. 100:214-233.

Bhattacharya, D. 1985. The demography of fronds of Chondrus crispus Stackhouse. J. Exp. Mar. Biol. Ecol. 91:217-31.

Bird, C.J., and McLachlan, J.L. 1992. Seaweed flora of the Maritimes. 1. Rhodophyta - the Red Algae. Biopress, Bristol, United Kingdom.

Cairns, D. K. (Editor) 2002. Effects of land use practices on fish, shellfish and their habitats on Prince Edward Island. Can. Tech. Rep. Fish. Aquat. Sci. No. 2408. 157 p.

Chopin, T., Bird, C.J., Murphy, C.A., Osborne, J.A., Patwary, M.U., and Floc'h, J-Y. 1996. A molecular investigation of polymorphism in the North Atlantic red alga Chondrus crispus (Gigartinales). Phycol. Res. 44:69-80.

Craigie, J.S., and Leigh, C. 1978. Carrageenans and agars. In Handbook of Phycological Methods: Physiological and Biochemical Methods. Edited by J.A. Hellebust and J.S. Craigie. Cambridge University Press, Cambridge, pp. 109-131.

Craigie, J.S., and Pringle, J.D. 1978. Spatial distribution of tetrasporophytes and gametophytes in four Maritime populations of Chondrus crispus. Can. J. Bot. 56:291014.

De Wreede, R.E., and Klinger, T. 1988. Reproductive Strategies in Algae. New York: Oxford University Press.

Dyck, L., De Wreede, R.E., and Garbary, D. 1985. Life history phases in Iridaea cordata (Gigartinaceae): Relative abundance and distribution from British Columbia to California. Jpn. J. Phycol. 33:225-32.

Garbary, D.J., and Kim, K.Y. 2005. Anatomical differentiation and photosynthetic adaptation in brown algae. Algae, 20:233.

Garbary, D.J., Miller, A.G., and Scrosati, R.A. 2014. Ascophyllum nodosum and its symbionts: XI. The epiphyte Vertebrata lanosa performs better photosynthetically when attached to Ascophyllum than when alone. Algae, 29:321.

Garbary, D.J., Tompkins, E., White, K., and Corey, P. 2011. Temporal and spatial variation in the distribution of life history phases of Chondrus crispus (Gigartinales, Rhodophyta). Algae, 26:61-71.

Garbary, D.J., and DeWreede, R.E. 1988. Life history phases in natural populations of Gigartinaceae (Rhodophyta): Quantification using Resorcinol. Experimental Phycology. A Laboratory Manual. Cambridge University Press, Cambridge, pp. 174-78.

Guidone, M., and Grace, S. 2010. The ratio of gametophytes to tetrasporophytes of intertidal Chondrus crispus (Gigartinaceae) across a salinity gradient. Rhodora, 112:80-84.

Judson, D., Gallant, R., and Howlett, P. 1987. Basin Head 'Giant'Irish moss biomass survey July-August 1987 and controlled harvest project. Report of the Prince Edward Island Department of Fisheries. 16 p.

Kim, K.Y., Jeong, H.J., Main, H.P., and Garbary, D.J. 2006. Fluorescence and photosynthetic competency in single eggs and embryos of Ascophyllum nodosum (Phaeophyceae). Phycologia, 45:331-36.

Krueger-Hadfield, S.A., Collén, J., Daguin-Thiébaut, C., and Valero, M. 2011. Distinguishing among genets and genetic population structure in the haploid-diploid seaweed Chondrus crispus (Rhodophyta). J. Phycol. 47:440-450.

Krueger-Hadfield, S.A., Roze, D., Destombe, C., Correa, J., and Valero, M. 2015. O father, where art thou? Paternity analyses in a natural population of the red seaweed Chondrus 
crispus. Heredity, 114:185-194.

Krueger-Hadfield, S.A., Roze, D., Mauger, S., and Valero, M. 2013. Intergametophytic selfing and microgeographic genetic structure shape populations of the intertidal red seaweed Chondrus crispus. Mol. Ecol. 22:3242-3260.

Lazo, L.M., Greenwell, M., and McLachlan, J. 1989. Population structure of Chondrus crispus Stackhouse (Gigartinaceae, Rhodophyta) along the coast of Prince Edward Island, Canada: Distribution of gametophytic and sporophytic fronds. J. Exp. Mar. Biol. Ecol. 126:45-58.

Lüning, K., Guiry, M.D., and Masuda, M. 1987. Upper temperature tolerance of North Atlantic and North Pacific geographical isolates of Chondrus species (Rhodophyta). Helgolander Meeresun. 41:297-306.

Lutz-Collins, V., Cox, R., and Quijón, P.A. 2016. Habitat disruption by a coastal invader: local community change in Atlantic Canada sedimentary habitats. Mar. Biol. 163:177.

Mathieson, A.C., and Burns, R.L. 1975. Ecological studies of economic red algae. V. Growth and reproduction of natural and harvested populations of Chondrus crispus Stackhouse in New Hampshire. J. Exp. Mar. Biol. Ecol. 17:137-56.

Mathieson, A.C., and Prince, J.S. 1973. Ecology of Chondrus crispus Stackhouse. Proceedings of the Nova Scotia Institute of Sciences, 27(Suppl.):53-79.

McCurdy, P. 1980. Investigation of a unique population of Chondrus crispus in Basin Head Harbour, Prince Edward Island. Report to National Research Council of Canada under Contract CS155-0-6302, 080-005, 34 pp.

McLachlan, J. 1991. Chondrus crispus (Irish moss), an ecologically important and commercially valuable species of red seaweed of the North Atlantic Ocean. In: Marine Biology: Its Accomplishment and Future Prospect. Edited by T. Mauchline and T. Nemoto. Elsevier, Amsterdam. pp. 217-233.

McLachlan, J., Greenwell, M., Bird, C.J., and Holmsgaard, J.E. 1987. Standing stocks of seaweeds of commercial importance on the north shore of Prince Edward Island, Canada. Bot. Mar. 38:277-290.

McLachlan, J.L., Quinn, J., and MacDougall, C. 1989. The structure of the plant of Chondrus crispus Stackhouse (Irish moss). J. Appl. Phycol. 1:311-17.

Pickering, T.R., and Quijón, P.A. 2011. Potential effects of a non-indigenous predator in its expanded range: Assessing green crab, Carcinus maenas (Linnaeus), prey preference in a productive shellfish area of Atlantic Canada. Mar. Biol. 158:2065-2078

Poirier, L.A., Symington, L.A., Davidson, J., St-Hilaire, S., and Quijón, P.A. 2017. Exploring the decline of oyster beds in Atlantic Canada shorelines: Potential effects of crab predation on American oysters (Crassostrea virginica). Helgol. Mar. Res. 71:13

Scrosati, R., Garbary, D.J., and McLachlan, J. 1994. Reproductive ecology of Chondrus crispus (Rhodophyta, Gigartinales) from Nova Scotia, Canada. Bot. Mar. 37:293-300.

Scrosati, R., and Mudge, B. 2004. Persistence of gametophyte predominance in Chondrus crispus (Rhodophyta, Gigartinaceae) from Nova Scotia after 12 Years. Hydrobiologia, 519:215-18.

Sharp, G.J. 1987. Growth and production in wild and cultured stocks of Chondrus crispus. In Twelfth International Seaweed Symposium. Edited by M.A. Ragan and C.L. Bird. Hydrobiologia 151/152: pp. 349-354.

Sharp, G., Semple, R., Connolly, K., Blok, R., Audet, D., Cairns, D., and Courtenay, S. 2003. Ecological assessment of the Basin Head lagoon: A proposed Marine Protected Area. Can. Manuscr. Rep. Fish. Aquat. Sci. 2641, 69 pp.

Sharp, G.J., Semple, R., Vandermeulen, H., Wilson, M., LaRocque, C., and Nebel, S. $2010 a$. The Basin Head Irish moss (Chondrus crispus) population abundance and distribution 
1980 to 2008. DFO Canadian Scientific Advisory Secretary Research Document, 2010/054. vi+32 p.

Sharp, G.J., Semple, R., Wilson, M., Larocque, C., Nebel, S., and Vandermeulen, H. $2010 b$. Ulva lactuca blooms in Basin Head lagoon, abundance and growth. Unpublished field report, Population Ecology Division, Bedford Institute of Oceanography.

Taylor, A.R.A., Chen, L.C.M., Smith, B.D., and Staples, L.S. 1981. Chondrus holdfasts in natural populations and in culture. Proceedings of the International Seaweed Symposium, 8:140-143.

van der Meer, J.P. 1990. Genetics. In Biology of the red algae. Edited by K. M. Cole and R.G. Sheath. Cambridge University Press, Cambridge, U.K. pp.103-121. 


\section{Figure captions}

Fig. 1. Map of Prince Edward Island (PEI) in the southern Gulf of St. Lawrence, and approximate location of North Rustico (NR), Hillsborough River (HR), Prim Point (PP) and Basin Head (BH). Inserts show the approximate location of sampling sites within HR and BH: Meadowbank (MB), Victoria Park (VP), Hillsborough Bridge (HB), Basin Head lagoon mouth (LM) and lagoon arm (LA).

Fig. 2. Mean $( \pm \mathrm{SE})$ minimum fluorescence $\left(F_{o}\right)$ in Chondrus crispus populations in Prince Edward Island: giant Irish moss populations grown in Basin Head (GM-BH) and NRC facilities (GM-NRC), and common Irish moss strains from Basin Head (BH), Point Prim (PP), Hillsborough Bridge (HB), Victoria Park (VP), Meadowbank (MB), and North Rustico (NR)

Fig. 3. Mean $( \pm \mathrm{SE})$ maximum quantum yield $\left(F_{v} / F_{m}\right)$ of photosynthesis in Chondrus crispus populations in Prince Edward Island. All other details as in Fig. 2. 

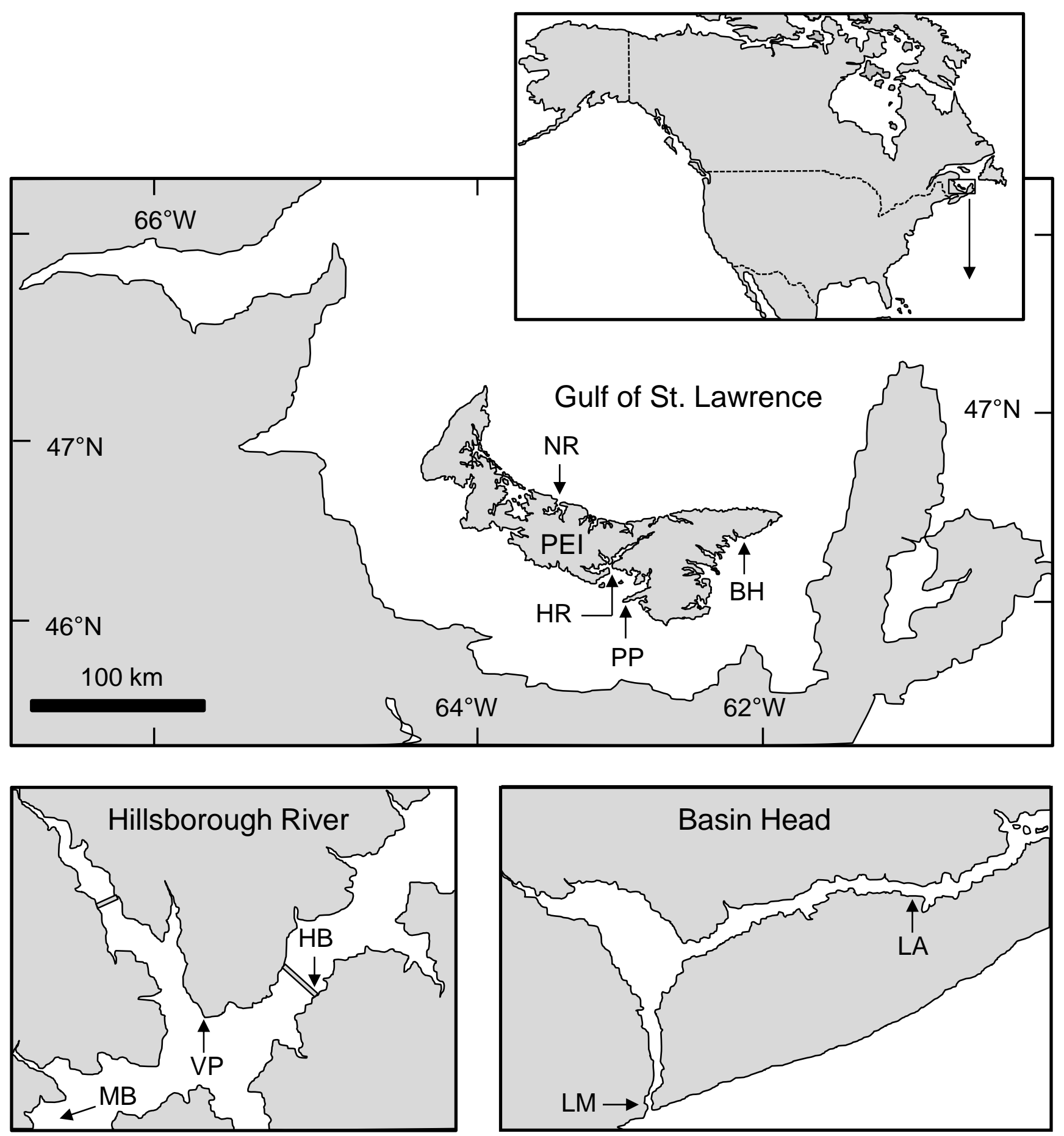


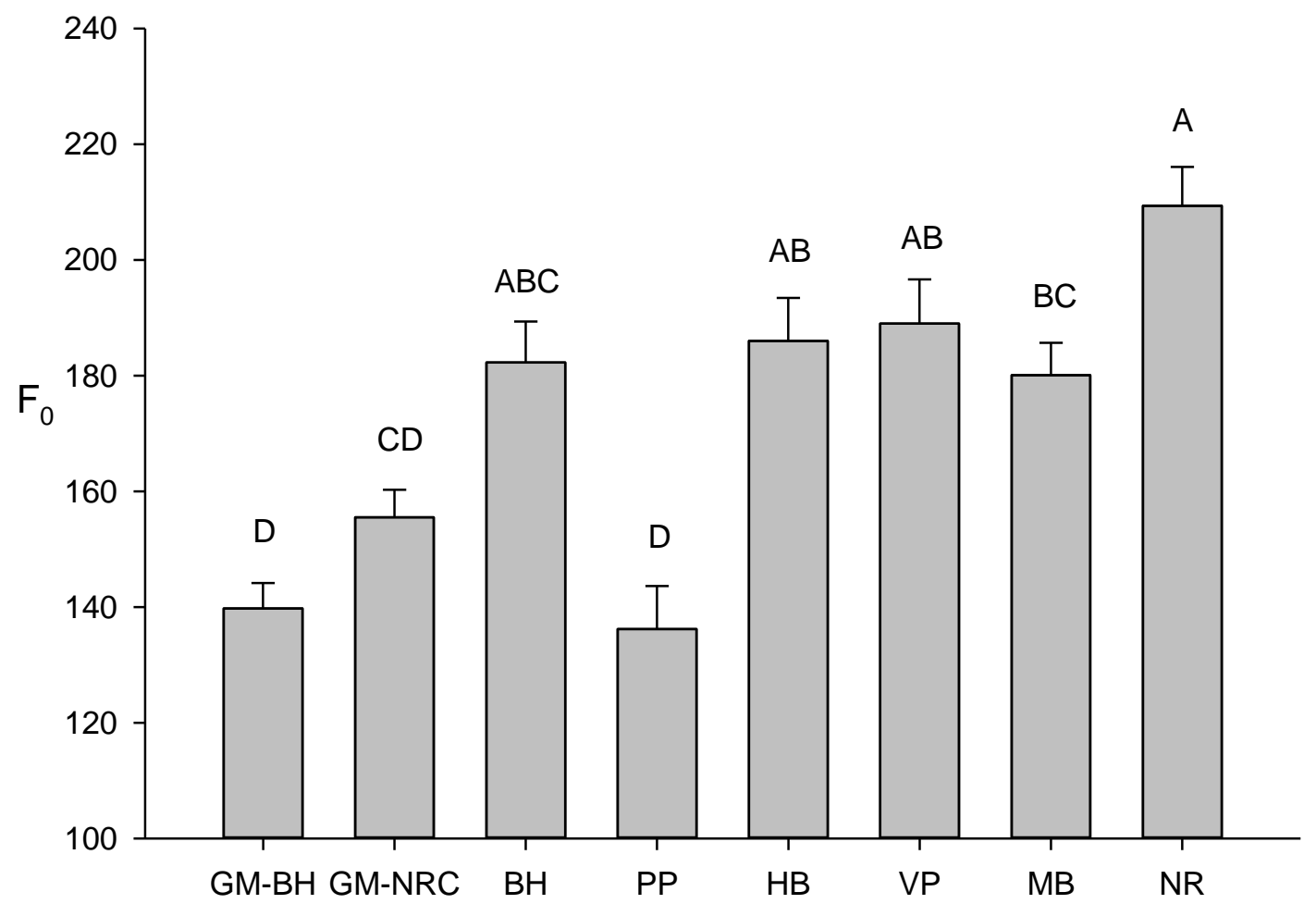




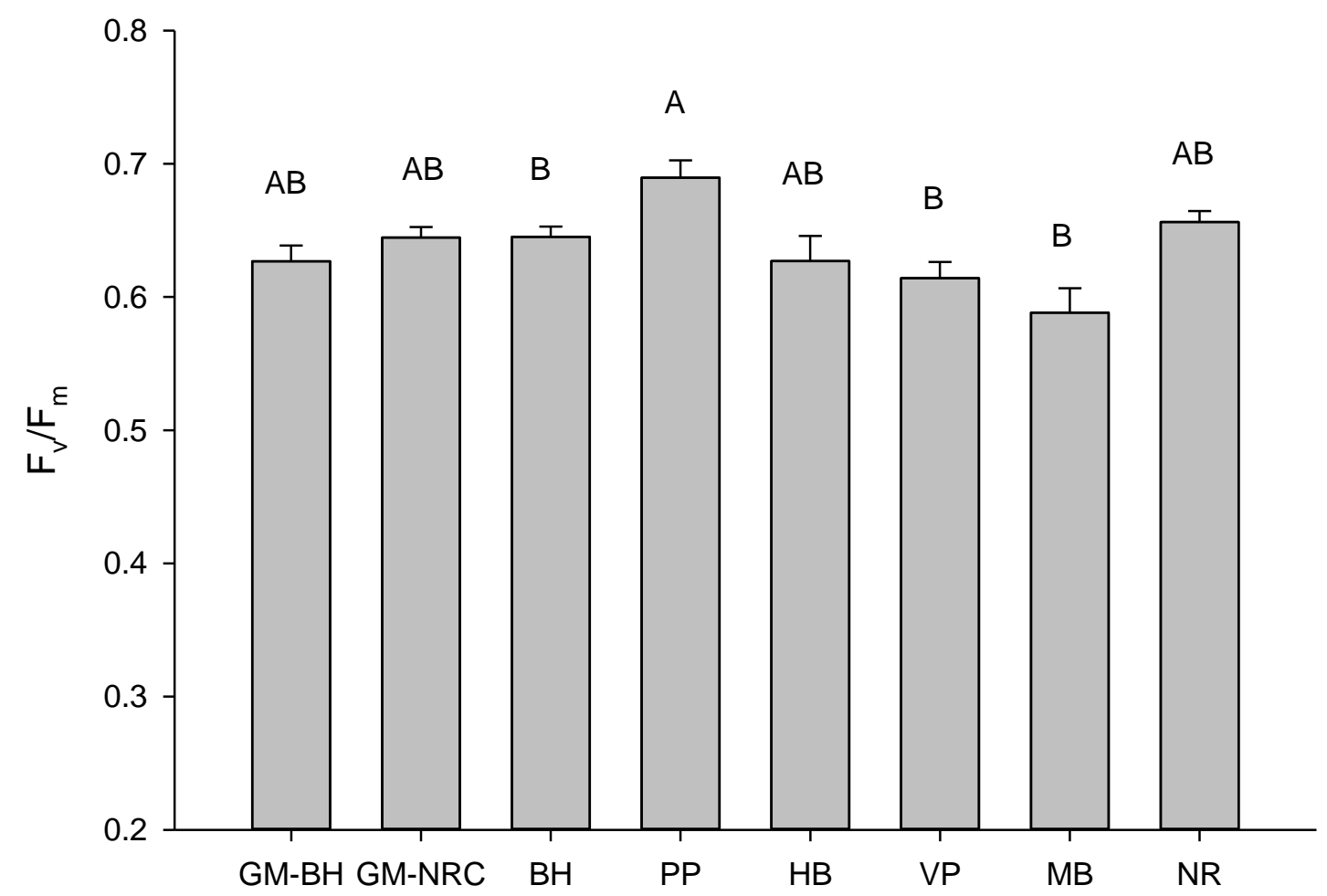


Table 1. Summary of Chondrus crispus sample populations from Prince Edward Island (and their location) analyzed for life history phase using the resorcinol-acetal test for carrageenan type and analyzed for photosynthetic performance.

\begin{tabular}{|c|c|c|c|c|c|}
\hline Irish moss Population & Lat, Long & Substrate & $\begin{array}{c}\text { Gametophyte } \\
(\%)\end{array}$ & $\begin{array}{c}\text { Sample size } \\
\text { (resorcinol-acetal test) }\end{array}$ & $\begin{array}{c}\text { Sample size } \\
\text { (fluorometry) }\end{array}$ \\
\hline Basin Head Giant Moss & $\begin{array}{l}46^{\circ} 23^{\prime} 27 " \mathrm{~N} \\
62^{\circ} 5^{\prime} 40^{\prime \prime} \mathrm{W}\end{array}$ & Mussels by byssal thread & 100 & 27 & 23 \\
\hline NRC Giant Moss & $\begin{array}{l}46^{\circ} 22^{\prime} 40^{\prime \prime} \mathrm{N} \\
62^{\circ} 6^{\prime} 31^{\prime \prime} \mathrm{W}\end{array}$ & Unattached & 100 & 100 & 28 \\
\hline Basin Head Common & $\begin{array}{l}46^{\circ} 22^{\prime} 40^{\prime \prime} \mathrm{N} \\
62^{\circ} 6^{\prime} 30^{\prime \prime} \mathrm{W}\end{array}$ & Metamorphic rocks & 79 & 100 & 26 \\
\hline Point Prim & $\begin{array}{l}46^{\circ} 3^{\prime} 54^{\prime \prime} \mathrm{N} \\
63^{\circ} 1^{\prime} 1 " \mathrm{~W} \\
\end{array}$ & $\begin{array}{l}\text { Shells and sandstone pebbles } \\
\text { (on sandy/muddy sediment) }\end{array}$ & 72 & 100 & 18 \\
\hline Hillsborough Bridge & $\begin{array}{l}46^{\circ} 14^{\prime} 2.60^{\prime \prime} \mathrm{N} \\
63^{\circ} 6^{\prime} 6.49^{\prime \prime} \mathrm{W} \\
\end{array}$ & Metamorphic rocks & 86 & 100 & 24 \\
\hline Victoria Park & $\begin{array}{l}46^{\circ} 13^{\prime} 39^{\prime \prime} \mathrm{N} \\
63^{\circ} 8^{\prime} 38^{\prime \prime} \mathrm{W}\end{array}$ & $\begin{array}{l}\text { Shells and sandstone pebbles } \\
\text { (on sandy/muddy sediment) }\end{array}$ & 74 & 99 & 28 \\
\hline Meadowbank & $\begin{array}{l}46^{\circ} 11^{\prime} 22^{\prime \prime} \mathrm{N} \\
63^{\circ} 14^{\prime} 10^{\prime \prime} \mathrm{W} \\
\end{array}$ & $\begin{array}{l}\text { Shells and sandstone pebbles } \\
\text { (on muddy sediment) }\end{array}$ & 65 & 97 & 27 \\
\hline North Rustico & $\begin{array}{l}46^{\circ} 27^{\prime} 17^{\prime \prime} \mathrm{N} \\
63^{\circ} 17^{\prime} 35^{\prime \prime} \mathrm{W}\end{array}$ & $\begin{array}{l}\text { Wharf, sandstone pebbles and } \\
\text { shells }\end{array}$ & - & - & 27 \\
\hline
\end{tabular}

